\title{
PEMIKIRAN EPISTEMOLOGI AMIN ABDULLAH DAN RELEVANSINYA BAGI PENDIDIKAN TINGGI DI INDONESIA
}

\author{
Waston \\ Universitas Muhammadiyah Surakarta \\ Jl A. Yani Pabelan Tromol Pos 1 Telp. (0271) 717417 Surakarta 57102 \\ E-Mail: waston.ums@gmail.com
}

\begin{abstract}
The relation between religion and science seems to be the dichotomous view. Both of them are like oil and water, two entities that cannot be reunited and separated. Due to "this dispute", science often misses their ethics, so science and modern technology have actually humanized humans and distanced them from their nature. The conflict between them forces many intellectual Muslims to make "epistemology bridge" for reconciling science and religion. One of them is M. Amin Abdullah, who argues with the concept of integration-interconnection which is the effort to avoid the dichotomous view of the science and religion (especially Islam-science) and in the epistemology view, the concept is to close back all disciplines so there are dialogues, communications, relationships, and mutual help. This article aims to discuss the epistemology thought of $M$. Amin Abdullah concerning on integration-interconnection with its methodology and relevance for the scientific development of higher education in Indonesia.
\end{abstract}

Keywords: Epistemology; Islam; science; Integration-interconnection.

\begin{abstract}
Abstrak: Hubungan antara agama dan ilmu pengetahuan tampaknya menjadi pandangan dikotomis. Keduanya ibarat minyak dan air, dua entitas yang tidak bisa bersatu kembali dan dipisahkan. Karena "sengketa ini" ilmu pengetahuan mencoba merangkul konsep-konsep agama dan etika agar ilmu pengetahuan-teknologi memiliki nuansa yang manusiawi. Konflik antara keduanya memaksa kaum Muslim intelektual membuat "jembatan epistemologi" untuk mendamaikan sains dan agama. Salah satunya adalah M. Amin Abdullah, yang berpendapat bahwa konsep integrasi-interkoneksi yang merupakan upaya untuk menghindari pandangan dikotomis dari ilmu dan agama (khususnya Islam-ilmu) dan dalam pandangan epistemologi, konsep ini mencoba menawarkan kembali semua disiplin ilmu sehingga ada dialogisasi, komunikasi, sinergitas, dan hubungan saling membantu. Artikel ini bertujuan untuk membahas epistemologi pemikiran M. Amin Abdullah berkenaan konsep integrasi-interkoneksi dengan metodologi dan relevansinya bagi pengembangan ilmu pengetahuan pendidikan tinggi di Indonesia.
\end{abstract}

Kata kunci: Epistemologi; Islam; ilmu pengetahuan; Integrasi-interkoneksi.

\section{PENDAHULUAN}

Kendati pun perkembangan sains dan teknologi di abad ke-21 ini telah mencapai kemajuan yang luar biasa, namun relasi agama dan ilmu tampaknya masih saja ber- corak dikotomik. Selain itu, relasi ilmu satu dengan ilmu lainnya juga hingga kini masih tampak berjalan sendiri-sendiri, tidak saling membutuhkan, tidak berhubungan, dan tidak saling 'bertegur sapa'. Tidak sedikit manusia modern yang menyakini bahwa 
sains dan agama merupakan entitas yang terpisah. Keduanya ibarat air dan minyak yang tidak dapat disatukan. Upaya untuk menyatukannya dianggap hanya akan mengurangi objektivitas sains dan juga sakralitas agama. ${ }^{1}$

Asumsi yang lama terpatri dalam back mind sebagian besar umat manusia adalah bahwa sains berangkat dari keragu-raguan, yang menggunakan metode ilmiah sebagai landasan dalam pencarian kebenaran, sedangkan agama berangkat dari sebuah keyakinan yang tidak dapat diganggu gugat. Agama dimulai dari keyakinan dengan metode yang dogmatis dan menggunakan teori kebenaran yang doktriner. Akibat "perseteruan" ini, sains kerap kehilangan pijakan etiknya, sehingga teknologi modern justru semakin tidak memanusiakan manusia dan menjauhkan manusia dari hakikat kemanusiannya. Bom nuklir yang meluluh-lantakkan Nagasaki dan Hiroshima, penggunaan senjata biokimia pada Perang Dunia I dan II, global warming, krisis energi, perubahan cuaca ekstrim, dan kerusakan ekologi adalah bukti kongkrit betapa sains telah kehilangan pijakan etik dan karenanya sering disalahgunakan.

Kian jauhnya sains dari nilai-nilai ag-

1 Terkait relasi sains dan agama, Ian Barbour, memetakannya dalam empat tipe, yaitu: independensi, konflik, dialog, dan integrasi. Tipe pertama adalah independensi yaitu ketika ilmu dan agama dilihat sebagai bidang yang berbeda dan ditempatkan dalam kotak sendiri-sendiri. Masing-masing memiliki otoritas di bidangnya masing-masing. Tipe kedua adalah konflik yaitu hubungan antara ilmu dan agama di mana keduanya saling melakukan ekspansi keluar dari bidangnya. Namun saat keduanya ini disatukan dalam satu kotak bersama terbukalah peluang untuk konflik. Tipe ketiga adalah dialog yaitu ketika antara ilmu dan agama membuka peluang untuk berkomunikasi, saling mendengar, saling menyapa satu sama lain. Tipe keempat adalah integrasi yang dimaknai Barbour dengan sangat spesifik yang bertujuan menghasilkan suatu reformasi teologi dalam bentuk theology of nature, yang berbeda dengan natural theology, yang tujuan utamanya untuk membuktikan kebenaran-kebenaran agama berdasar temuan-temuan ilmiah. Ian Barbour, Religion in An Age of Science (New York: Harper Collins Publisher, 1990), hlm. 4. ama menjadikan banyak intelektual Muslim merasa terpanggil untuk bertanggung jawab membuat semacam "jembatan penyeberangan", sehingga keduanya dapat dipertemukan kembali. Kendati pun menyisakan banyak perdebatan, beberapa ilmuwan Muslim, baik intelektual Muslim Indonesia maupun intelektual Muslim dari belahan bumi lainnya, telah mencoba merumuskan semacam "jembatan epistemologis" untuk merujukkan kembali sains dan agama. Salah satunya adalah M. Amin Abdullah, yang menawarkan paradigma integrasi-interkoneksi keilmuan. Selain berupaya menghilangkan dikotomi sains dan agama (terutama dikotomi Islam-sains), proyek keilmuan yang digagasnya tersebut juga berupaya "mendekatkan kembali" berbagai disiplin ilmu, sehingga di antara mereka terjadi dialog, tegur sapa, saling berhubungan, dan saling membutuhkan.

Penelitian deskriptif ini akan membedah lebih kritis, ilmiah dan mendalam pemikiran epistemologi M. Amin Abdullah dan relevansinya bagi pengembangan keilmuan perguruan tinggi di Indonesia. Sebelum lebih jauh mendiskusikan pemikiran epistemologinya, terlebih dahulu akan dibahas sekelumit biografi M. Amin Abdullah.

M. Amin Abdullah² lahir di Margomulyo, Tayu, Pati, Jawa Tengah, 28 Juli 1953. Menamatkan Kulliyat Al-Mu'allimin Al-Islamiyyah (KMI), Pesantren Gontor Ponorogo 1972 dan Program Sarjana Muda (Bakalaureat) pada Institut Pendidikan Darussalam (IPD) 1977 di Pesantren yang sama. Menyelesaikan Program Sarjana pada Fakultas Ushuluddin, Jurusan Perbandingan Agama, IAIN Sunan Kalijaga Yogyakarta, tahun 1982. Atas sponsor Departemen Agama dan Pemerintah Republik Turki, mulai tahun 1985 mengambil Program Ph.D. bidang Filsafat Islam, di Department of Philosophy, Faculty of Art and Sciences, Middle East Technical University (METU), Ankara, Turki (1990). Ia pernah mengikuti Program Post Doctoral di McGill University,

2 https://aminabd.wordpress.com/perihal. Diakses pada 15 Mei 2016. 
Kanada (1997-1998).

Disertasinya yang berjudul The Idea of University of Ethical Norms in Ghazali and Kant, diterbitkan di Turki (Ankara: Turkiye Diyanet Vakfi, 1992). Karya-karya ilmiah lainnya yang diterbitkan, antara lain: Falsafah Kalam di Era Postmodernisme(Yogyakarta: Pustaka Pelajar, 1995); Studi Agama: Normativitas atau Historisitas(Yogyakarta: Pustaka Pelajar, 1996). Dinamika Islam Kultural : Pemetaan atas Wacana Keislaman Kontemporer, (Bandung, Mizan, 2000); Antara al-Ghazali danKant : Filsafat Etika Islam, (Bandung: Mizan, 2002) serta Pendidikan Agama Era Multikultural Multireligius, (Jakarta: PSAP Muhammadiyah, 2005). Sedangkan karya terjemahan yang diterbitkan adalah $A g$ ama dan Akal Pikiran: Naluri Rasa Takut dan Keadaan Jiwa Manusiawi (Jakarta: Rajawali, 1985); Pengantar Filsafat Islam: Abad Pertengahan (Jakarta: Rajawali, 1989).

M. Amin Abdullah pernah menjadi Ketua Perhimpunan Pelajar Indonesia (PPI), Turki, 1986-1987. Sembari memanfaatkan masa liburan musim panas, pernah bekerja part time pada Konsulat Jenderal Republik Indonesia, Sekretariat Badan Urusan Haji, di Jeddah (1985 dan 1990), Mekkah (1988), dan Madinah (1989), Arab Saudi. Kini, sebagai dosen tetap Fakultas Ushuluddin, staf pengajar pada Program Doktor Pascasarjana IAIN (sekarang UIN) Sunan Kalijaga, IAIN Sunan Ampel Surabaya, Universitas Islam Indonesia, Program Magister pada UIN Sunan Kalijaga, Ilmu Filsafat, Fakultas Filsafat dan Program Studi Sastra (Kajian Timur Tengah), Fakultas Sastra, Universitas Gadjah Mada, Yogyakarta. Tahun 1993-1996, menjabat Asisten Direktur Program Pascasarjana IAIN Sunan Kalijaga; 1992-1995 menjabat Wakil Kepala Lembaga Pengkajian dan Pengamalan Islam (LPPI) Universitas Muhammadiyah Yogyakarta. Tahun 1998-2001 sebagai Pembantu Rektor I (Bidang Akademik) di almamaternya, IAIN Sunan Kalijaga. Pada Januari 1999 mendapat kehormatan menjadi Guru Besar dalam Ilmu Filsafat. Dari tahun 2002-2005 sebagai Rektor IAIN/UIN Sunan Kalijaga. Tahun 2005-2010 sebagai Rektor UIN Sunan
Kalijaga Yogyakarta untuk Periode kedua.

Dalam organisasi kemasyarakatan, Guru Besar UIN Sunan Kalijaga ini pernah menjadi Ketua Divisi Ummat, ICMI, Orwil Daerah Istimewa Yogyakarta, 1991-1995. Setelah Muktamar Muhammadiyah ke-83 di Banda Aceh 1995, diberi amanat sebagai Ketua Majelis Tarjih dan Pengembangan Pemikiran Islam, Pimpinan Pusat Muhammadiyah (1995-2000). Kemudian terpilih sebagai salah satu Pimpinan Pusat Muhammadiyah, Wakil Ketua (2000-2005).

Tulisan-tulisan bernasnya dapat dijumpai di berbagai jurnal keilmuan, antara lain Ulumul Qur'an (Jakarta), Al-Jami'ah: Journal of Islamic Studies (Yogyakarta) dan beberapa jurnal keilmuan keislaman yang lain. Di samping itu, dia aktif mengikuti seminar di dalam dan luar negeri. Seminar internasional yang diikuti, antara lain: "Kependudukan dalam Dunia Islam", Badan Kependudukan Universitas AlAzhar, Kairo, Juli 1992; tentang "Dakwah Islamiyah", Pemerintah Republik Turki, Oktober 1993; Lokakarya Program Majelis Agama ASEAN (MABIM), Pemerintah Malaysia, di Langkawi, Januari 1994; "Islam and $21^{\text {st }}$ Century", Universitas Leiden, Belanda, Juni 1996; "Qur'anic Exegesis in the Eve of $21^{\text {st }}$ Century", Universitas Leiden, Juni 1998, "Islam and Civil Society: Messages from Southeast Asia", Tokyo Jepang, 1999; "alTa'rikh al- Islamy wa azamah al-huwaiyah", Tripoli, Libia, 2000; "International anti-corruption conference", Seol, Korea Selatan, 2003; Persiapan Seminar "New Horizon in Islamic Thought", London, Agustus, 2003; "Gender issues in Islam", Kuala Lumpur, Malaysia, 2003; "Dakwah and Dissemination of Islamic Religious Authority in Contemporarry Indonesia", Leiden, Belanda, 2003.

\section{METODE PENELITIAN}

Jenis penelitian yang digunakan dalam penulisan ini adalah library research. Bodgan dan Biklen menyimpulkan bahwa studi ini juga dikategorikan sebagai penelitian kualitatif. Dikatakan kualitatif, karena studi ini 
lebih menekankan pada pendeskripsian pemikiran M. Amin Abdullah, terutama pemikiran tentang konsep epistemologi ilmu. Karena fokusnya pada deskriptif, maka penelitian ini juga bersifat alamiah dan induktif. Sebagaimana diungkapkan Bodgan dan Biklen, bahwa penelitian kualitatif memiliki lima karakteristik khusus, yaitu: (a) naturalistik, (b) deskriptif, (c) perhatian pada proses, (d) induktif, dan (e) perhatian pada makna. $^{3}$

Sedangkan pendekatan yang digunakan dalam penelitian ini adalah pendekatan filosofis dan pendekatan sejarah. Nata ${ }^{4}$ menyatakan bahwa historis atau sejarah adalah suatu ilmu yang di dalamnya dibahas berbagai peristiwa dengan memperhatikan unsur tempat, waktu, obyek, latar belakang, dan pelaku dari peristiwa tersebut. Pendekatan lain dalam penelitian ini adalah pendekatan biografi, Komaruddin ${ }^{5}$ beralasan karena memaparkan tentang pemikiran atau pun pandangan tokoh, agamawan, politikus, ataupun sejarawan. Selain itu, penulis juga memakai pendekatan normatif, yaitu untuk merumuskan kesimpulan-kesimpulan mengenai keadaan dan kaidah yang berlaku pada obyek penelitian.

Sumber data primer diperoleh langsung dari subyek penelitian dengan mengenakan alat pengukur atau alat pengambilan data langsung pada subyek sebagai sumber informasi yang dicari. Teknik analsis datanya menggunakan Content analysis, sebagaimana ungkapan Suryabrata ${ }^{6}$ bahwa conten analysis adalah menganalisis data sesuai dengan kandungan isinya. Dengan ini data-data yang penulis kumpulkankan adalah bersifat deskriptif dan data tekstual yang bersifat fenomenal, maka dalam mengelola data-data tersebut penulis menggunakan

3 Robert C. Bodgan dan Sari Knopp Biklen, Qualitative Research for Education: An Introduction to Theory and Methods, London: Allyn and Bacon, 1998, hlm. 4-5.

4 Abuddin Nata, Metodologi Studi Islam, Jakarta: Raja Grafindo Persada, 1998. hlm. 59.

5 Komaruddin, Metode Penelitian Kualitatif, Yogyakarta: Pustaka Pelajar, 1991, hlm. 72.

6 Sumardi Suryabrata, Metode Penelitian, Jakarta: Rajawali Press, 1998, hlm. 94. analisis ini. Dengan analisis ini penulis akan melakukan analisis data secara ilmiah dan menyeluruh tentang konsepsi dan pemikiran M. Amin Abdullah, yaitu dengan cara: a) komparatif, b) deskriptif, dan c) induktif. Selanjutnya, karena penelitian ini merupakan studi tokoh dan sejarah, maka langkah-langkah yang digunakannya meliputi: a) pemilihan topik, b) pengumpulan sumber, c) verifikasi (kritik sejarah, keabsahan sumber), d) interpretasi (analisis dan sintesis), e) historiografi atau penulisan, dan f) penyimpulan.

\section{HASIL DAN PEMBAHASAN}

Pemikiran epistemologi M. Amin Abdullah antara lain dapat disimak melalui pemaparannya tentang epistemologi Islam, yaitu: epistemologi bayani, irfani, dan burhani. Pemikiran epistemologi M. Amin Abdullah mengadopsi dan sangat dipengaruhi oleh pemikiran epistemologi M. Abid AlJabiry. Fakta ini dapat dijumpai dalam karya M. Amin Abdullah, Islamic Studies di Perguruan Tinggi: Pendekatan Integratif-Interkonektif. Ia menyebutkan bahwa kedua buku al-Jabiry, yaitu Takwin al-aql Araby dan Bunyah al-aql Araby: Dirasah Tahliliyyah naqdiyyah li nudzumi al-ma'rifah fi al-tsaqafah al-Arabiyyah, cukup representatif untuk meneropong struktur fundamental kefilsafatan ilmu kajian-kajian keislaman dalam ranah humanities. Sementara buku ketiga alJabiry, al-Aql al-siyasy al-Araby, merupakan realisasi dari konsep-konsep dan paradigma humanities dalam pemikiran keislaman dalam ranah kehidupan sosial-politik yang kongkrit dalam masyarakat Muslim.

Pengaruh kuat al-Jabiry atas pemikiran Amin Abdullah dikemukakan oleh Carool Kersten, dosen senior Studi Islam dan Dunia Muslim di King's College London, yang menyebutkan bahwa Amin Abdullah mengambil epistemologi bayani, burhani, dan irfani yang dikembangkan al-Jabiry. Kersten lebih lanjut mengatakan bahwa menurut Amin Abdullah, pendekatan kritis Al-Jabiry mencakup wilayah yang sangat mirip dengan filsafat ilmu Barat dan kare- 
nanya ia mengusulkan sesuatu yang belum pernah dilakukan sebelumnya dalam kajian Islam seperti mengaplikasikan teori-teori filsuf ilmu seperti: Karl Popper, Thomas Kuhn, dan Lakatos, untuk mengkaji Islam. ${ }^{7}$

Dalam konteks ini, M. Amin Abdullah menawarkan pendekatan komprehensif terhadap studi agama sebagai wilayah terbuka dan interdisipliner, yang tampak pada Islam sebagai agama yang hidup (living realigion). Hal ini dimksudkan untuk mengkaji Islam melalui lensa peradaban dengan menggunakan disiplin ilmu sekuler modern dan juga disiplin ilmu keagamaan tradisional, yang dikombinasikan dengan pendekatan etis-filosofis, yang tidak berpretensi bebas nilai. ${ }^{8}$

Bagi M. Amin Abdullah, epistemologi bayani, irfani dan burhani yang digagas Al-Jabiry menyediakan struktur bagi transformasi studi Islam multidisipliner kontemporer ke dalam abad 20 versi pendekatan komprehensif al-Ghazali terhadap ilmuilmu keagaman konvensional abad ke-11. Hal ini menciptakan dialog antar keduanya, sehingga 'memanusiakan' kajian Islam dibanding 'mengislamkan' pengetahuan. ${ }^{\text {' }}$

Menurut M. Amin Abdullah, ada 3 (tiga) model pola hubungan antara epistemologi bayani, irfani, dan burhani. Pertama, model pola hubungan pararel. Pada model ini masing-masing corak epistemologi akan berjalan sendiri-sendiri tanpa ada hubungan dan persentuhan antara yang satu dengan yang lain dalam diri seorang ilmuwan, ulama, aktivis, dan agamawan. Nilai manfaat yang akan diperoleh, baik teoretis maupun praktis dari model pola hubungan pararel, minim sekali. Bentuk hubungan pararel mengasumsikan bahwa dalam diri seorang ilmuwan terdapat tiga jenis epistemologi keilmuan agama Islam sekaligus,

7 Carool Kersten, "A Moroccan Philosopher in Indonesia: The Influence of Muhammad Abid al-Jabiri on Indonesian Islamic Teaching", http:// caroolkersten.blogspot.co.id/2015/02/a-moroccan-philosopher-in-indonesia.html. Diakses pada 7 Mei 2016.

8 Ibid.

9 Ibid. namun masing-masing epistemologi tersebut berdiri sendiri-sendiri dan tidak saling berdialog dan berkomunikasi antara satu dengan yang lain. ${ }^{10}$

Kedua, model pola hubungan linier. Pola hubungan linier berasumsi bahwa salah satu dari ketiga epistemologi tersebut akan menjadi primadona. Seorang ilmuwan akan mengabaikan epistemologi lain karena ia secara apriori menyukai dan mengunggulkan salah satu dari tiga jenis epistemologi yang ada. Jenis epistemologi yang ia pilih danggap sebagai satu-satunya epistemologi yang paling ideal dan final. Model pilihan semacam ini akan mengantarkan seseorang pada kebuntuan seperti kebuntuan dogmatis-teologis, yang biasanya terekspresikan pada truth claim yang berlebihan dan eksklusivistik. ${ }^{11}$

Ketiga, model pola hubungan sirkular. Masing-masing corak epistemologi keilmuan dapat memahami keterbatasan, kekurangan, dan kelemahan yang melekat pada diri masing-masing sekaligus bersedia mengambil manfaat dari temuan-temuan yang ditawarkan oleh tradisi keilmuan yang lain serta memiliki kemampuan untuk memperbaiki kekurangan yang melekat pada dirinya sendiri. Dengan demikian, kekakuan, kekeliruan, ketidaktepatan, anomali-anomali yang melekat pada masing-masing epistemologi dapat dikurangi dan diperbaiki setelah mendapatkan masukan dan kritik dari jenis epistemologi lain, baik epistemologi bayani, irfani, maupun burhani. ${ }^{12}$

Dari ketiga model pola hubungan epistemologi di atas, model yang dominan yang terjadi pada model pendidikan di Indonesia dan sebagaian besar negara-negara Islam lainnya adalah model pola hubungan pararel dan linear. Tentu saja, realitas semacam ini merupakan sesuatu yang memperihatinkan sekaligus merisaukan. Padahal, setiap disiplin keilmuan sejatinya tidak dapat dip-

10 M. Amin Abdullah, Islamic Studies di Perguruan Tinggi: Pendekatan Integratif-Interkonektif (Yogyakarta: Pustaka Pelajar, 2006), hlm. 219.

11 Ibid., hlm. 220.

12 Ibid., hlm. 223-224. 
isahkan dari disipilin ilmu-ilmu yang lain dan tidak dapat berdiri sendiri. Merespons realitas tersebut, M. Amin Abdullah, mengatakan bahwa setiap bangunan keilmuan apa pun, baik keilmuan agama (termasuk agama Islam dan agama-agama yang lain), keilmuan sosial-humaniora, maupun kealaman tidak dapat berdiri sendiri. Ketika ilmu pengetahuan tertentu mengklaim dapat berdiri sendiri, merasa dapat menyelesaikan persoalan secara mandiri, serta tidak memerlukan bantuan dan sumbangan dari ilmu yang lain, maka self sufficiency ini cepat atau lambat bakal berubah menjadi narrowmindedness untuk tidak menyebutnya fanatisme partikularitas disiplin keilmuan. Karena itu, kerjasama, saling tegur sapa, saling membutuhkan, saling koreksi, dan saling keterhubungan antar disiplin keilmuan akan lebih dapat membantu manusia memahami kompleksitas kehidupan yang dijalaninya dan menyelesaikan problematika yang dihadapinya. ${ }^{13}$

Untuk menyelesaikan dikotomi keilmuan (antara keilmuan agama dan keilmuan umum), mantan Rektor UIN Sunan Kalijaga ini, secara konseptual menawarkan paradigma integrasi-interkoneksi.
Melalui paradigma ini, dialog keilmuan yang bersifat integratif-interkonektif selain dilakukan dalam wilayah internal ilmu-ilmu keislaman, dikembangkan pula integrasi-interkoneksi ilmu-ilmu keislaman dengan ilmu-ilmu umum. Masing-masing rumpun memiliki keterbatasan dan karenanya harus berdialog, kerjasama, serta memanfaatkan metode dan pendekatan rumpun ilmu lain untuk melengkapi kekurangan-kekurangan masing-masing. Proyek keilmuan ini berupaya mendialogkan segitiga keilmuan, yakni hadlarah an-nash (keilmuan agama yang bersumber pada teks-teks), hadlarah al-ilm (ilmu-ilmu sosial dan ilmu-ilmu kealaman), dan hadlarah al-falsafah (keilmuan etis-filosofis).

Paradigma integrasi-interkoneksi merupakan upaya mempertemukan kembali antara ilmu-ilmu keislaman (Islamic sciences) dengan ilmu-ilmu umum (modern sciences), dengan harapan tercapainya kesatuan ilmu yang integratif dan interkonektif. Proses ini diharapkan menjadi solusi dari berbagai krisis yang melanda manusia dan alam belakangan ini sebagai akibat ketidakpedulian suatu ilmu terhadap ilmu yang lain yang selama ini terjadi.

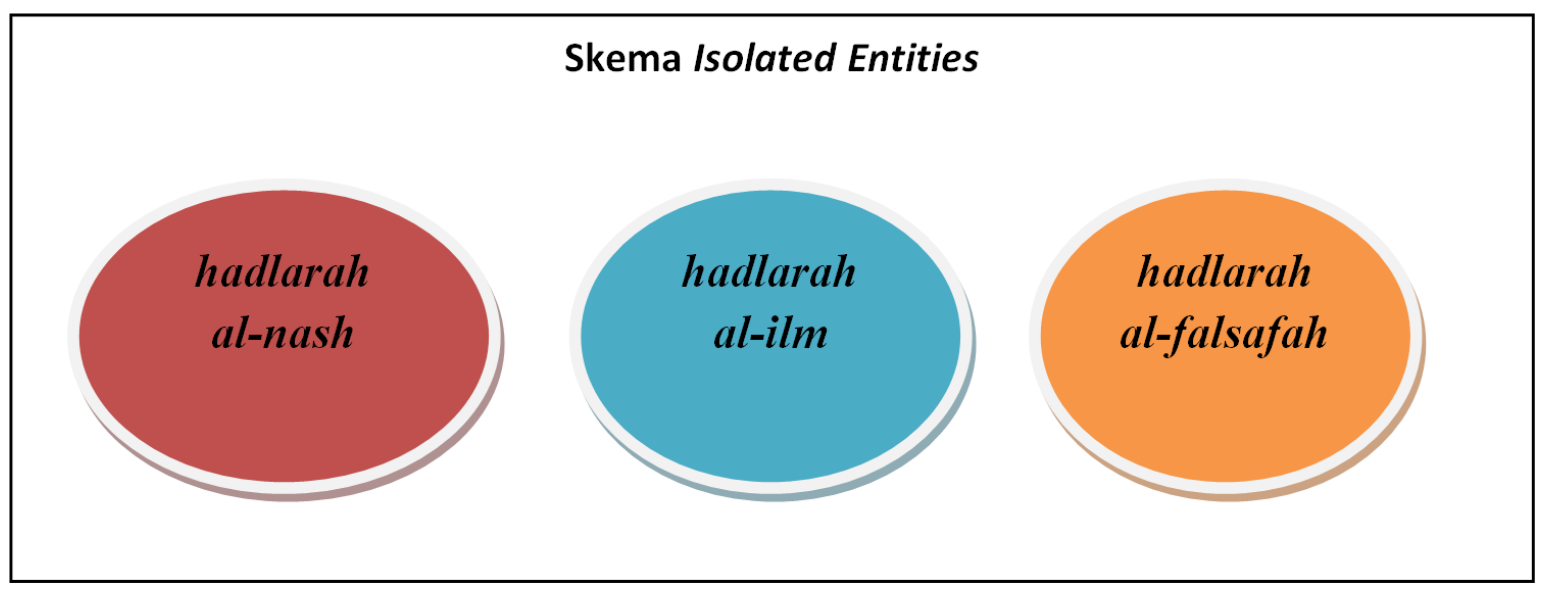

Tampak dalam skema di atas peradaban manusia telah kian maju karena adanya ketiga entitas keilmuan tersebut. Konfigurasi hubungan yang isolated tersebut diyakini menjadi sumber problematika dunia kontemporer semisal krisis lingkungan hidup, ekonomi, moralitas, religiusitas, dan kri- sis-krisis lainnya. ${ }^{14}$ Skema demikian, dapat ditransformasikan ke dalam suatu bentuk keilmuan yang interkonektif (interconnected entities).

13 Ibid., hlm., vii-viii.

14 Ibid., hlm. 404. 


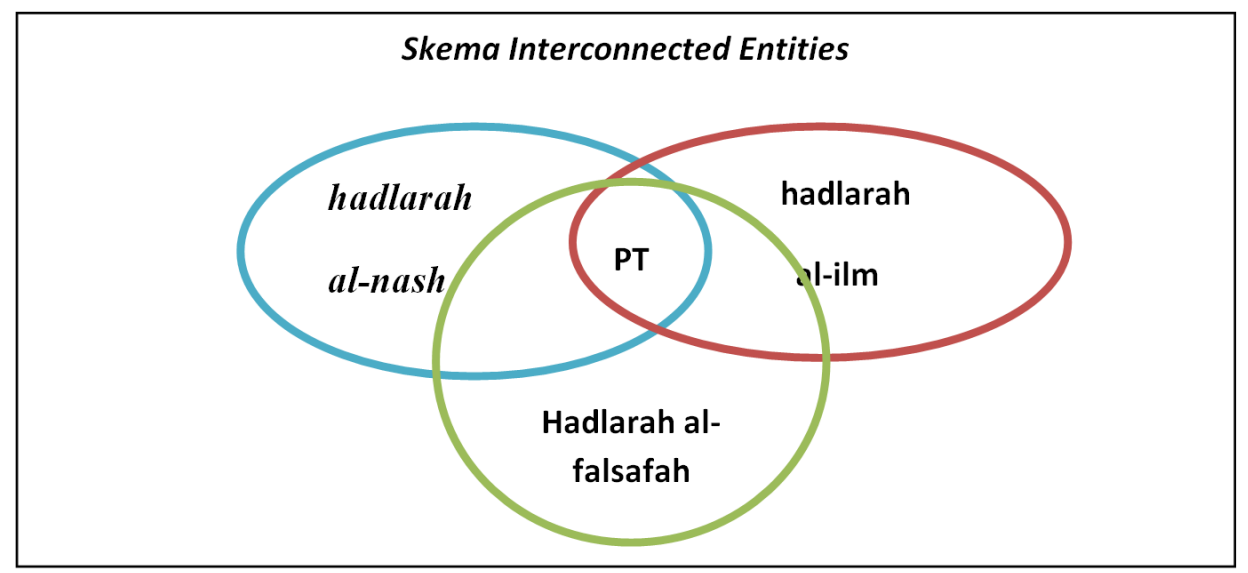

Tampak dalam skema di atas bahwa setiap rumpun ilmu memiliki keterbatasan-keterbatasan yang melekat dalam dirinya dan karenanya, harus bersedia untuk berdialog, bekerjasama, dan memanfaatkan metode dan pendekatan yang dipakai oleh rumpun ilmu lain untuk melengkapi kekurangan yang melekat pada dirinya. ${ }^{15}$

Secara paradigmatik-filosofis, ada 3 (tiga) aspek yang hendak dintrodusisasi oleh paradigma integrasi-interkoneksi. Pertama, secara epistemologis, paradigma integrasi-interkoneksi merupakan respons terhadap kesulitan-kesulitan yang dirasakan selama ini, yang diwariskan dan diteruskan selama berabad-abad dalam peradaban Islam tentang adanya dikotomi pendidikan umum dan pendidikan agama. Masing-masing berdiri sendiri-sendiri, tanpa merasa perlu saling bertegur sapa. Dikotomi ini diperparah dengan berdirinya Kementerian Pendidikan dan Kebudayaan dan Kementerian Agama yang mengurusi pendidikan di negeri ini. Kedua, secara aksiologis, paradigma integrasi-interkoneksi hendak menawarkan pandangan dunia (world view) manusia beragama dan ilmuwan yang baru, yang lebih terbuka, mampu membuka dialog dan kerjasama, transparan, dapat dipertanggungjawabkan secara publik dan berpandangan ke depan. Ketiga, secara ontologis, hubungan antar berbagai disiplin keilmuan menjadi kian terbuka dan cair, kendati pun blok-blok dan batas-batas wilayah antara budaya pendukung hadlarah

15 Ibid., hlm. 405. al-nash dan budaya pendukung hadlarah alilm serta budaya pendukung hadlarah al-falsafah masih tetap saja ada. ${ }^{16}$

Untuk memahami konsep integrasi-interkoneksi keilmuan secara komprehensif, M. Amin Abdullah selanjutnya mememperkenalkan paradigma keilmuan jaring laba-laba (spider web) bercorak teoantroposentris-integralistik.

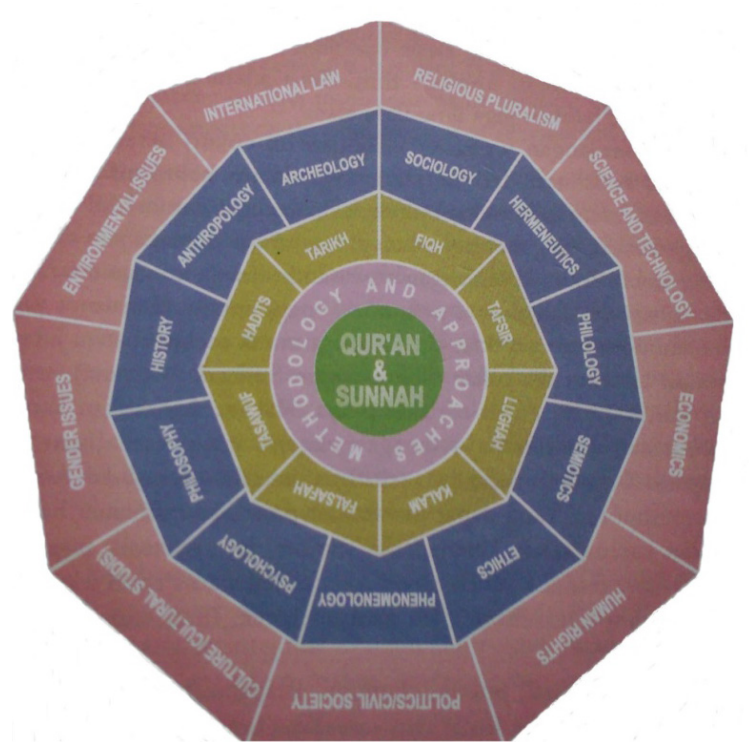

Gambar di atas mengilustrasikan bahwa jarak pandang atau horizon keilmuan integralistik begitu luas, sekaligus terampil dalam perikehidupan sektor tradisional maupun modern lantaran dikuasainya salah satu ilmu dasar dan keterampilan yang dapat menopang kehidupan di era informasi-globalisasi. Selain itu, tergambar sosok manusia beragama (Islam) yang

16 Ibid., hlm. vii-ix. 
terampil dalam menangani dan menganalisis isu-isu yang menyentuh problem kemanusiaan dan keagamaan di era modern dan posmodern dengan dikuasainya berbagai pendekatan baru yang diberikan oleh ilmu-ilmu alam (natural sciences), ilmu-ilmu sosial (social sciences) dan humaniora ( $h u-$ manities) kontemporer. Di atas segalanya, dalam setipa langkah yang ditempuh, senantiasa diikuti landasan etika-moral keagamaan yang objektif dan kokoh, karena keberadaan al-Qur'an dan As-Sunnah yang dimaknai secara baru (hermeneutis) selalu menjadi landasan pijak pandangan hidup (weltanschauung) keagamaan manusia yang menyatu dalam satu nafas keilmuan dan keagamaan. Semua itu didedikasikan untuk kesejahteraan manusia secara bersama-sama tanpa memandang latar belakang etnisitas, ras, agama maupun golongan. ${ }^{17}$

Melalui gambar jaring laba-laba keilmuan tersebut, M. Amin Abdullah juga mengkritik bahwa radius jangkauan aktivitas keilmuan pada Perguruan Tinggi Agama Islam (PTAI) di Indonesia yang hanya terfokus pada lingkar 1 dan jalur lingkar lapis 2 (Kalam, Falsafah, Tasawuf, Hadis, Tarikh, Fiqh, Tafsir, Lughah). Itu pun, menurut Doktor Ankara University ini, hanya terbatas pada ruang gerak pendekatan keilmuan humaniora klasik. PTAI pada umumnya belum mampu memasuki diskusi ilmu-ilmu sosial dan humanities kontemporer seperti yang tergambar pada jalur lingkar 2 (antropologi, sosiologi, psikologi, filsafat serta berbagai teori dan pendekatan yang ditawarkannnya). Alhasil, terjadi jurang wawasan keilmuan yang tak terjembatani antara ilmu-ilmu klasik dan ilmu-ilmu keislaman baru yang telah memanfaatkan analisis ilmu-ilmu sosial dan humaniora, bahkan juga ilmu-ilmu alam. Lebih dari itu, isu-isu

17 M. Amin Abdullah, "Etika Tauhidik sebagai Dasar Kesatuan Epistemologi Keilmuan Umum dan Agama (dari Paradigma Positivistik-Sekularistik Ke Arah Teoantroposentrik-Integralistik)", dalam M. Amin Abdullah, dkk,. Menyatukan Kembali Ilmu-Ilmu Agama dan Umum: Upaya Mempersatukan Epistemelogi Islam dan Umum, (Yogyakarta: Sunan Kalijaga Press, 2003), hlm. 12. sosial, politik, ekonomi, keagamaan, militer, gender, ekologi, ilmu-ilmu sosial-humaniora kontemporer posmodern sebagaimana tergambar pada jalur lingkar lapis 3 hampir-hampir tidak tersentuh oleh ilmu-ilmu sosial dan kajian keislaman di negeri ini. ${ }^{18}$

Relevansi Pemikiran Epistemologi M. Amin Abdullah terhadap Pengembangan Keilmuan Perguruan Tinggi

Pemikiran epistemologi M. Amin Abdullah melalui paradigma integrasi-interkoneksi senantiasa relevan dijadikan sebagai pijakan pengembangan keilmuan perguruan tinggi di Indonesia, terutama bagi perguruan tinggi Islam dan atau perguruan tinggi berbasis Islam seperti Perguruan Tinggi Muhammadiyah (PTM). Paradigma integrasi-interkoneksi dapat dijadikan paradigma keilmuan perguruan tinggi (terutama perguruan tinggi Islam dan atau berbasis Islam) untuk mengembangkan model keilmuan yang non-dikotomik

Dalam konteks pengembangan keilmuan di perguruan tinggi, paradigma integrasi-interkoneksi secara kongkrit dapat diimplementasikan dalam berbagai level: ${ }^{19}$

\section{a. Level filosofi}

Integrasi dan interkoneksi pada level filosofis dalam pengajaran mata kuliah adalah bahwa setiap mata kuliah harus diberikan nilai fumndamental eksistensial dalam kaitannya dengan disiplin keilmuan lain dan dalam hubungannya dengan nilai-nilai humanistik. Mengajarkan fiqh misalnya di samping makna fundamentalnya sebagai filosofi membangun hubungan antara manusia, alam dan Tuhan dalam ajaran Islam, dalam pengajaran fiqh harus ditanamkan pula pada mahasiswa bahwa eksistensi fiqh tidaklah sendiri atau bersifat self-sufficient, melainkan berkembang bersama sikap

18 Ibid., hlm. 13-14.

19 Bermawy Munthe, dkk., Sukses Belajar di Perguruan Tinggi: Sosialisasi pembelajaran di Perguruan Tinggi bagi Mahasiswa Baru UIN Sunan Kalijaga (Yogyakarta: CTSD UIN Sunan Kalijaga, 2015), hlm. 15-17. 
akomodatifnya terhadap disiplin keilmuan lainnya seperti filsafat, sosiologi, psikologi, dan sebagainya.

b. Level materi

Implementasi integrasi dan interkoneksi pada level materi dapat dilakukan dengan tiga model pengejawantahan interkoneksitas keilmuan antar disiplin keilmuan. Perta$m a$, model pengintegrasian ke dalam pengajaran mata kuliah. Kedua, model penanaman mata kuliah yang menunjukan hubungan antara dua disiplin ilmu umum dan keislaman. Model ini menuntut setiap mata kuliah mencantumkan kata Islam seperti ekonomi Islam, politik Islam, sosiologi Islam, dan lain-lain. Ketiga, model pengintegrasian ke dalam pengajaran mata kuliah.model ini menuntut setiap mata kuliah keislaman dan keagamaan harus diinjeksikan teori-teori keilmuan umum terkait sebagai wujud interkoneksitas antara keduanya. Sebaliknya dalam setiap pengajaran mata kuliah ilmuilmu umum harus diberikan wacana-wacana teoretik keislaman dan keagamaan.

\section{c. Level metodologi}

Ketika disiplin ilmu diintegrasikan atau diinterkoneksikan dengan disiplin ilmu lain, misalnya psikologi dengan nilai-nilai Islam, maka secara metodologis, ilmu interkonektif tersebut harus menggunakan pendekatan dan metode yang aman bagi ilmu tersebut. Sebagai contoh pendekatan fenomenologis yang memberi apresiasi empatik dari orang-orang yang mengalami pengalaman, dianggap lebih aman ketimbang pendekatan lain yang mengandung bias anti-agama seperti psikoanalisis. Dari sisi metode penelitian tidak menjadi masalah karena suatu penelitian yang dilakukan secara objektif maka hasilnya adalah kebenaran objektif. Kebenaran seperti ini justru akan mendukung kebenaran agama itu sendiri.

\section{d. Level strategi}

Level strategi yang dimaksud di sini adalah level implementasi/praksis dari proses pembelajaran keilmuan integratif-in- terkonektif. Dalam konteks ini, setidaknya kualitas keilmuan serta ketrampilan mengajar dosen menjadi kunci keberhasilan perkuliahan berbasis paradigma interkoksitas. Di samping kualitas-kualitas ini, dosen mesti difasilitasi dengan baik menyangkut pengadaan sumber bacaan yang beragam serta bahan-bahan pengajaran (teaching resources) di kelas. Demikian pula pembelajaran dengan model pembelajaran active learning dengan berbagai strategi dan metodenya menjadi sebuah keniscayaan. ${ }^{20}$

\section{KESIMPULAN}

Dengan implementasi paradigma integrasi-interkoneksi di perguruan tinggi (Islam dan atau berbasis Islam), di samping dapat memangkas dikotomi keilmuan, ke depannya diharapkan pula dapat mengantarkan perguruan tinggi (Islam dan atau berbasis Islam) mencapai kemajuan, terutama dalam pengembangan sains dan teknologi. Sebab, telah menjadi rahasia umum, penguasaan sains dan teknologi di dunia Islam sangat rendah. Menurut Azyumardi Azra, ada sejumlah indikator kasar yang dapat dijadikan ukuran untuk menilai rendahnya penguasaan sains dan teknologi. Menurutnya, sampai detik ini, sebagian besar negara Islam adalah produsen bahan mentah seperti minyak, gas alam, karet, minyak sawit, biji makanan, kapas, dan gula tebu. Sumber perekonomian di banyak negara Islam adalah pertambangan dan pertanian. Pabrik yang dapat memproduksi nilai tambah hanya menjadi bagian kecil dari seluruh perekonomian sebagian besar negara Islam. Dalam bidang pertanian, negara-negara Islam tertinggal dalam aspek penelitian dan pengembangan pertanian serta agrobisnis dibanding negara lain.

Direktur Sekolah Pascasarjana UIN Syarif Hidayatullah ini lebih lanjut mengemukakan bahwa lemahnya riset dan pengembangan ilmiah di sebagian besar negara-negara Islam terkait dengan realitas institusi-institusi sains yang dimiliki keban-

20 M. Amin Abdullah, Islamic Studies, hlm. 99. 
yakan negara-negara Islam belum berfungsi optimal untuk mendorong penemuan-penemuan ilmiah. Di Barat dan negara-negara lain, institusi sains terus tumbuh untuk mengantisipasi era globalisasi, sementara di hampir kebanyakan negara Islam pertumbuhannya sangat lambat. Di kebanyakan negara Islam, jumlah institusi-institusi riset sains masih sangat rendah; anggaran yang dialokasikan untuk program-program ilmiah hampir tidak memadai; jumlah komunitas ilmiah dan produktivitas ilmuwan juga masih rendah. Beberapa kelemahan tersebut erat kaitannya dengan tingkat pendidikan di dunia Islam. ${ }^{21}$

Last but not least, tantangan di era globalisasi menuntut respons cepat dan tepat dari sistem pendidikan Islam secara keseluruhan. Bila umat Muslim tidak hanya ingin sekedar survive di tengah kompetisi global yang kian ketat namun juga hendak tampil di depan, maka reorientasi pemikiran pen-

21 Azyumardi Azra, "Reintegrasi Ilmu-Ilmu dalam Islam", dalam Zainal Abidin Bagir, dkk, Integrasi Ilmu dan Agama: Interpretasi dan Aksi, (Bandung: Mizan, 2005), hlm. 203-205. didikan Islam serta rekonstruksi sistem dan kelembagaan merupakan sebuah keniscayaan.

Mudah-mudahan apa yang dilakukan M.Amin Abdullah dapat mendudukkan filsafat sebagai landasan pengembangan ilmu pengetahuan. Yakni, untuk memastikan bahwa perkembangan ilmu pengetahuan tak menjadi pedang Damocles akibat kehampaannya dari perspektif tujuan pengembangan ilmu itu sendiri-yakni kebahagiaan manusia, dan bukan sekedar kemakmuran atau kekuasaan materialistik-dan juga absennya etika di ujung penerapannya-yang bisa berakibat kontraproduktif terhadap tujuan pengembangan ilmu pengetahuan itu sendiri. Di Dunia Islam, nilai penting integrasi-interkoneksi keilmuan ini bahkan lebih besar dari pada itu. Yakni untuk mengangkat ummat Islam dari kubangan kemundurannya di bidang ini, mengingat bahwa filsafat pernah terbukti menjadi dorongan terbesar bagi kemajuan ilmu pengetahuan di belahan dunia ini.

\section{DAFTAR PUSTAKA}

Abdullah, M. Amin, "Etika Tauhidik sebagai Dasar Kesatuan Epistemologi Keilmuan Umum dan Agama (dari Paradigma Positivistik-Sekularistik Ke Arah Teoantroposentrik-Integralistik)", dalam M. Amin Abdullah, dkk,. Menyatukan Kembali IlmuIlmu Agama dan Umum: Upaya Mempersatukan Epistemelogi Islam dan Umum, Yogyakarta: Sunan Kalijaga Press, 2003.

- Islamic Studies di Perguruan Tinggi: Pendekatan Integratif-Interkonektif, Yogyakarta: Pustaka Pelajar, 2006.

Azra, Azyumardi, “Reintegrasi Ilmu-Ilmu dalam Islam”, dalam Zainal Abidin Bagir, dkk, Integrasi Ilmu dan Agama: Interpretasi dan Aksi, Bandung: Mizan, 2005.

Barbour, Ian, Religion in An Age of Science, New York: Harper Collins Publisher, 1990.

https://aminabd.wordpress.com/perihal. Diakses pada 15 Mei 2016.

Kersten, Carool, "A Moroccan Philosopher in Indonesia: The Influence of Muhammad Abid al-Jabiri on Indonesian Islamic Teaching", http://caroolkersten.blogspot. co.id/2015/02/a-moroccan-philosopher-in-indonesia.html. Diakses pada 7 Mei 2016.

Munthe, Bermawy, dkk., Sukses Belajar di Perguruan Tinggi: Sosialisasi pembelajaran di Perguruan Tinggi bagi Mahasiswa Baru UIN Sunan Kalijaga, Yogyakarta: CTSD UIN Sunan Kalijaga, 2015. 